\begin{tabular}{l|l|l|l|l}
\hline Volume 1 & Issue 2 & August (2020) & DOI: 10.47540/ijsei.v1i2.23 & Page: $97-107$ \\
\hline
\end{tabular}

\title{
Validating Children's Stories and Decisions after Trafficking for Prostitution
}

\author{
Ifeyinwa Mbakogu
}

School of Social Work Dalhousie University, Canada

Corresponding Author: Ifeyinwa Mbakogu; Email: ifeyinwa.mbakogu@dal.ca

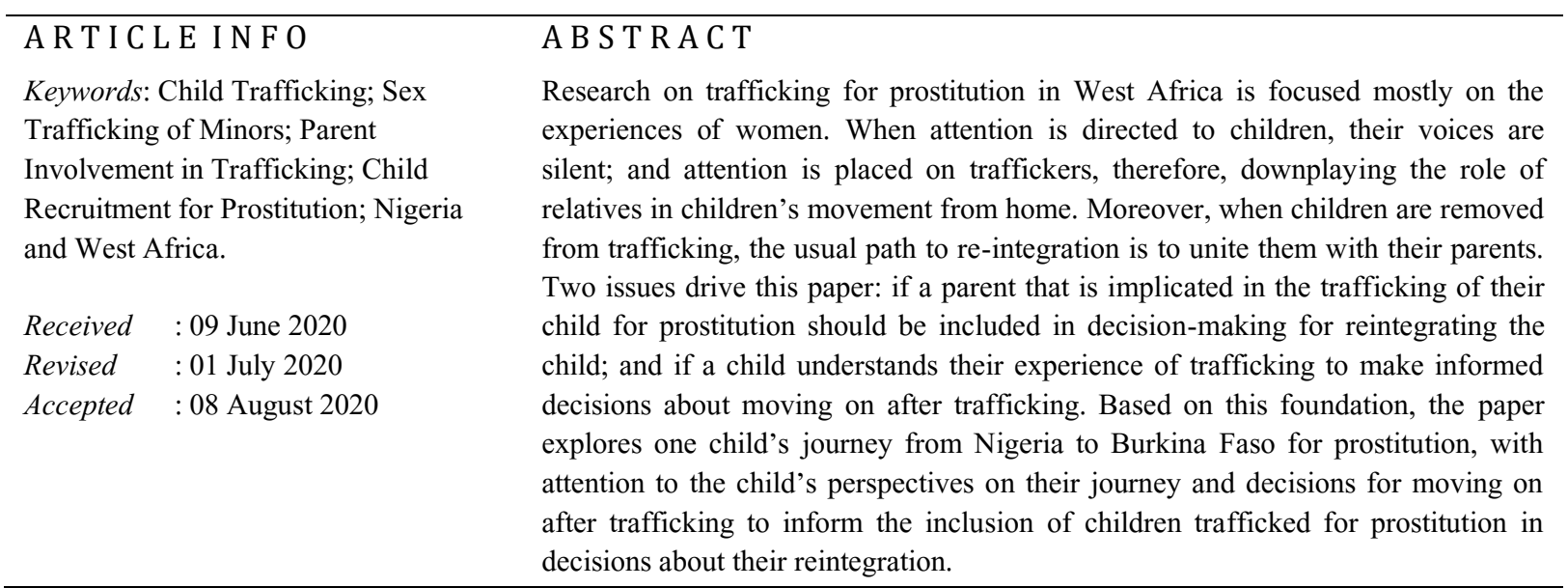

\section{INTRODUCTION}

A number of African countries have adopted the definition offered by The UN Protocol to Prevent, Suppress and Punish Trafficking in Persons, especially Women and Children (2000) which defines child trafficking as: "...the recruitment, transportation, transfer, harboring, or receipt of any person under the age of eighteen for the purposes of sexual or labor exploitation, forced labor, or slavery." The UN Protocol provides a legal framework for explaining situations in which children could be considered trafficked thus: The recruitment, transportation, transfer, harboring, or receipt of a child for the purpose of exploitation shall be considered "trafficking in persons" even if this does not involve any of the means (such as force or inducements to obtain the consent of another) set forth in subparagraph (a) of this article (UNODC, 2000, p. 43).

The UN Protocol's definition of child trafficking, therefore, waives procuring children by fraudulent means. This implies that children are considered victims of trafficking even when trafficking has occurred without children being deceived (Kooijmans and van de Glind, 2010). This waiver is important within the context of trafficking in
Nigeria where consent for trafficking may be given by parents, children, or children's guardians (Nwogu, 2007; UNICEF, 2007). Prior to the UN definition of child trafficking, it was difficult to prosecute trafficking agents in situations where parents in a bid to escape poverty gave consent to their children's trafficking. The definition also allows parents to be held accountable for permitting acts that exploit a minor. The intention is probably that when parents are liable to be prosecuted for exploiting their children, then the tendency to hand their children over to traffickers will reduce.

The involvement of parents and related others in children's journey into and out of trafficking is particularly relevant to this paper and the case study around a Nigerian child that will be explored. The paper will present events leading to the new interest in trafficking for sexual exploitation in Nigeria, the voicelessness of trafficked children and the merit of concentrating on a case study from a larger study, the research methodology and the discussions of findings informed by Promise's journey into trafficking.

Briefly, the trafficking of Nigerian girls to Italy began in the 1980s as a result of economic depression in Nigeria and the adoption of the 
Structural Adjustment Programme imposed by the World Bank and International Monetary Fund (Agbatise, 2004; Ogwezzy, 2011). Economic deprivations forced many Nigerians to search for better opportunities in Europe, Saudi Arabia, the United States, and other countries (Adepoju, 2005). There were also successive governments that looted the Nation's treasury with illegal transfers of these funds into foreign accounts. These actions, which increased the country's debt vulnerabilities, mostly affected the rural and urban poor, comprising women, children and other marginalized groups (Onimode, 1992).

The economic decline forced parents to seek alternative means of survival that included sending their young children to work in the homes of richer relatives living in urban areas in exchange for salaries, thereby monetizing the age-old African child fostering practice (Akor, 2011). Women were also more vulnerable to trafficking because of cultural, social and institutional discriminatory practices that prevent women from inheriting properties, having access to credit from financial institutions and participating in decision making relating to their wellbeing (Onyejekwe, 2005). Because men and women do not have similar privileges, men are more likely to be involved in more economic-based decision-making and property ownership than women (Fayomi, 2009).

Furthermore, the economic downturn in the country and a heightened need for alternative means of survival meant that migration became a favoured option for several Nigerians. It was easier for educated Nigerians than the less educated to obtain visas and work permits. However, stringent immigration laws, introduced by governments in destination and departure countries, only enhanced the market for services such as fake travelling documents and illegal transportation (smuggling) all of which encouraged illegal migration (Adepoju, 2005; Germano, 2001). With this illegal opening, young girls and boys began leaving Nigeria on promises of well-paid jobs in factories, offices and farms in Europe. In the early stages of young people's migration to the European country, Italy, it was possible for women and girls to work in tomato fields and undertake menial jobs. Then, human traffickers saw an opportunity to make a profit and moved in. The business of trafficking in humans gained momentum because traffickers were able to collude with corrupt government officials in countries across the globe (Agbu, 2003; Nwogu, 2006). By the 1990s, more Nigerian females who had been deliberately tricked were arriving in Italy to find themselves sold into slavery and prostitution (IOM, 1996). To buttress the established nature of the sexual exploitation of Nigeria women in Italy, Aghatise (2004, p. 1129) adds that: “... a number of those who came to Italy during the 1980 s ended up as madams who later perpetuated the sex trade by becoming exploiters of their countrywomen..." Thus, the vicious circle of prostitution persists.

Not much attention was given to the trafficking in women and children in West Africa until two African Non-Governmental Organizations (NGOs), the Nigerian based Constitutional Rights Project and the Togo-based WAO-Afrique gave initial alerts about the presence of child trafficking within their territories in September 1996 and May 1997 respectively (Adepoju, 2005). Also, in 1997, the then Nigerian Ambassador to Italy, Ms Judith Attah, drew the attention of the 63rd Interpol General Assembly's Nigerian delegation to the growing presence of Nigerian girls as prostitutes in that country (Ebigbo, 2003). Moreover, between 1999 and 2000, 500 Nigerian women and girls were deported from Italy (Ojomo, 2000). Further insight on the state of child trafficking in West Africa was presented in 2001, with media reports of a Nigerianregistered ship, the MV Etireno, which sailed from Cotonou, Benin ostensibly carrying 250 children from the African countries of Benin and Togo to the oil-rich country of Gabon. When the ship eventually made a mysterious return and docked in Cotonou, only about 23 children were found on board (BBC News, 2001; Kielland and Bjørkhaug, 2009). Also, in 2001, the foreign media was agog with stories of the torso of a young boy found floating in the River Thames. The boy who came to be referred to as "Adam" had his DNA traced to South-Western Nigeria. Investigations led to the arrest of a trafficking ring specializing in body parts used for ritual purposes (Pile, 2006).

With these global occurrences and the increased deportation of Nigerian girls from Italy and other European countries, the Nigerian government recognized that trafficking was indeed a problem and made concerted efforts to address it. The first of these was the enactment of an antitrafficking law and the creation of an agency, the 
National Agency for the Prohibition of Trafficking in Persons (NAPTIP) with the power to oversee legislative and policy platforms for addressing human trafficking.

While the paper begins by tracing a guiding global protocol and a historical context for the interest in the trafficking of Nigerian women and girls, the paper is focused on the silent inattention to trafficking of children for prostitution within West Africa itself. With inattention to the problem is the limited voice of children that are survivors of trafficking. With the rise in cases of child trafficking, there has been growing interest in getting the input of children in research that relates to their wellbeing and survival (Mbakogu, 2012). The increased need to involve children in research that is about their lives, experiences and motivations for activities such as trafficking is largely influenced by the recognition in new studies of childhood and child rights (Spyrou, 2011; Veeran, 2004) that children have rights and could inform research and policy-making by providing their reasons for explaining their experiences of the world the way they do (James and Prout, 1997). This recent focus, questions thoughts about children and childhood across cultures; and acknowledges that similar to adults, children have different explanations of their experiences and are active participants in shaping their world (James and Prout, 1997).

Goździak (2008) also reinforces the idea of involving children in research by emphasizing that limited knowledge of the experiences of trafficked children provided by trafficked children themselves: "...impedes identification of trafficked children, obstructs provision of culturally appropriate and effective services, and limits prevention of repeat victimization” (p. 909). GoŹdziak’s remark also amplifies the difficulty researchers encounter in gaining access to and working with trafficked children. In an attempt to project children's experiences and voice in research and post trafficking decisions, the paper explores the following research questions:

1) Should a parent that was implicated in the trafficking of their child for prostitution be included in decisions for reintegrating the child?

2) Does a child have an adequate understanding of their experience of trafficking to make informed decisions about moving on after trafficking?

Following the methods section, the rest of the paper will focus on the narratives of a child survivor of trafficking for prostitution within a regional (not international) context to show how a child was put in a position of helplessness by older people (parent included) they trusted to provide them with counsel or direction.

\section{MATERIALS AND METHOdS}

This paper is informed by a larger study that centers children's voice within trafficking research. The study aspired to: understand the needs of child survivors of trafficking, express their voices in research, and contribute to determining appropriate services for children removed from trafficking. Qualitative research tools, including interviews, focus group discussions and arts-based methods were used to collect data from child participants. Purposive sampling was explored to select child participants removed from trafficking across demographic variables that included: age, gender, geographical/regional location and their residency within shelters managed by government or NGOs. The researcher worked with more than 100 child survivors of trafficking within a period of 10 months, with the final number of participants narrowed to more than 50 children that completed all the data gathering tools. The children that participated in the larger study were citizens of four West African countries - Ghana, Nigeria, Togo and Benin. The children who were under 18 years were recruited for diverse forms of trafficking (such as domestic servitude, sexual exploitation, caregiving, witchcraft accusation and workers in employer's business enterprises) and resident in NAPTIP shelters in Nigeria after their removal from trafficking within West Africa.

Ethics approval was obtained from McGill University's Research Ethics Board prior to interacting with children. The researcher ensured that the ethics guidelines were followed in obtaining the assent of children in shelter care and consent from agency personnel who were considered children's temporary or official guardians prior to the study.

The research process was explained to the children that participated in the study and children were told that they could opt-out of the research at 
any time should they experience discomfort. Children decided the time of application of the research tool, the location for discussions and the duration of engagement with the researcher. Personal interviews were estimated to last for about 30 minutes and the sessions were recorded with the assent of participating children. The researcher ensured that the interview questions were openended and flexible enough to respond to the moods and needs of participating children. The interview questions for children were structured to understand the nature of their departure from home and how children interpreted their experiences - which is different from how adults who did not have these experiences interpret them on behalf of children. The major intent of the larger study and the paper is to present children's words as they uttered them, which is uncommon in trafficking research where researchers feel they have to speak on behalf of children (Mbakogu, 2015).

Data generated from children's narratives reflected their level of comfort during the research process. The narratives with children for the study were transcribed by the researcher, organized and content analyzed. The themes that were generated from the narrative of the focus child, inform the findings and discussions in this article with links to related literature. The themes build around: difference and lost childhood; resistance; parents' involvement and betrayal; and advocacy to safeguard other children.

\section{RESULTS AND DISCUSSION}

Building on the economic foundation of the child trafficking literature, parents are often mentioned as sending their children into trafficking because they fell for the deceptive manipulations and promises of trafficking agents. While it could be true that some parents motivated by concerns about their children's future and household wellbeing could make hasty and unfortunate decisions, the study also sought to know what affected children had to say about their journey into trafficking. The paper will explore Promise's narrative of her journey away from home and decisions concerning reintegration on returning to her country of origin.

\section{Parents' involvement and betrayal}

Promise is 17 years old and from one of the states in the South-South geo-political zone of
Nigeria. Promise is the fourth of eight children. Her father passed away and her mother remarried and had 3 children for her new husband. Promised said that she became tired of the breaks in her schooling due to lack of funds and dropped out of school after her Junior Secondary School 3 (JSS3). Promise told her mother that rather than the on and off school attendance, she would prefer to be enrolled to learn a trade. One day her mother who Promise mentions is a practising seer or visionary, told her that she will be travelling to Senegal to work as domestic servant to an 'oyinbo' [White person].

They don't know each other but the woman is our church member. She said that her brother took people to outside [abroad]...I had doubts about the outside that we were going. I said no that she should look for another person to give the man that I am not going... My mother asked the woman the type of work and she said that I am going to serve oyinbo [white person] in Senegal. It was the woman that told the man not to tell us that it is prostitute work. So, the man was even ready to tell us. If the man had told me, I will not go anywhere. Hmm, it is only the man that is not from our church...

Promise had doubts about this nicely packaged trip to work in Senegal but her mother believed her church member when she said that Promise will be traveling to work for a Whiteman. Promise did not want to leave home with a strange man introduced to her mother by a female church member, but after much persuasion and threats, she obeyed her mother. Ordinarily one will expect that a church member will be the best person to tell you the true nature of a job you will perform outside your country. The church member was not only silent but forced the trafficker to silence because of the anticipated profit.

Several authors and policy-makers attest that child trafficking is one of the fastest-growing organized crimes in the world (Fitzgibbon, 2003; Marinova and James, 2012; Wennerholm, 2002). Trafficking thrives because it is a profitable business requiring little start-off capital that compensates for the risks involved. An agent or recruiter could earn from $\$ 50$ to $\$ 1000$ for successfully delivering children to future employers within Africa. An agent earns even more, as much as $\$ 10,000$ to $\$ 20,000$, for delivering an African 
child to the United States (Fitzgibbon, 2003). The annual profit from human trafficking for traffickers is $\$ 150$ billion, distributed across: commercial sexual exploitation ( $\$ 99$ billion); Construction and manufacturing ( $\$ 34$ billion); agriculture and fishing (\$9 billion); and savings made by households recruiting domestic servants who are either not paid or under-paid ( $\$ 8$ billion) as at 2014 (ILO report, 2014).

Promise's journey into trafficking began from Nigeria when the link man asked Promise and her older cousin traveling with her to take an oath. The two girls refused. Later on, the girls found themselves traveling to Burkina-Faso instead of Senegal and handed over to a woman who they told Promise was now her madam. The madam told Promise that she will be working as a prostitute, a job which Promise refused. Promise requested to speak with her mother before making further decisions about how to deal with her complicated situation in Burkina-Faso. Promise was still tearful as she recalled the conversation she had with her mother from faraway Burkina-Faso:

...the woman now started saying that if we work, we will bring money for food. I said that I want to go to Nigeria, that I am not eating. The woman now started forcing me and my sister. I used the woman's phone to call my mother... I called my mother and my mother now said that I should not do the work for the first time, that I should not do the work o! That we are Christians, that our church doesn't do that kind of work. She started crying. She cut the phone. I called her back. She said that I should manage the work, that there is no money in Nigeria. I said oh! Then she [mother] started forcing me to do the work. I said that I cannot do it, that I am very little; I am too small to want to do this work. She now said I should say if I am a virgin...that I used to meet men in Nigeria before. I asked how she knows that I always sleep with men in Nigeria. She said that she knows. I told her that I am not going to do the work and she started forcing me... She said that there is no work in Nigeria. I started crying...

It was observed during the interview that the child never accused her mother of wrongfully telling her that she was to work for oyinbo in
Senegal while finding herself in Burkina-Faso instead. The child still believed in her mother's innocence. The pain experienced by the child was more related to the huge knocks on the parental foundation. First, when Promise told her mother that she was asked to work as a prostitute, she appeared happy that her mother was opposed to this based on their religious background. However, after she redialled her mother's phone number, she spoke with a completely different person. Her mother told her to endure the job for the sake of the family. Finding she could not trust the closest person to her, Promise must have been really shaken and felt resigned to her fate. It can only be imagined how children's perception of parental betrayal influenced their participation in or endurance of exploitative trafficking.

\section{Resistance during Trafficking}

The child was brave in exhibiting that initial resistance against remaining in a place and performing services that would potentially cause immense discomfort. After Promise, realized that her mother did not want her to return to Nigeria empty-handed, she battled with her captors the best way she could.

The woman [madam] took me to a woman that speaks my language. My sister and I stayed in the woman's house. The woman took me to a bar. The name of the bar is XB. My sister and I started working there. I do not like to work. I will just sit down and start crying. I will not carry men. They said that I should be carrying men because they don't sell drinks there. It's for Burkina people... So, they now started---I do not like carrying men. I will just stay in one place. [She gives a pained reflective laugh.] If I carry one I will be busy, me and the man will be fighting inside. He will ask me to return his money, I will return it and he will go. So, they were complaining and telling my madam that I don't carry men fast that I will be beating the men, that me and men will be fighting inside.

Promise did not want to work as a prostitute, and she expressed this to her captors. But no one listened to her or noticed her tears until she started turning customers away, which was bad for business. But how long can resistance exhibited by withholding services to customers be tolerated in the sex trade? It is even more difficult to prolong 
resistance when a child is in a strange country, does not speak or understand the language and is unable to navigate law enforcement services. However, the child soon learns that resistance strengthens their traffickers' resolve to keep them in their employ and withstand situations of exploitative servitude. When this realization dawns, resistance weakens to turn into complete submission until someone rescues the child from captivity.

\section{'Difference' and lost childhood}

When a child's body and labor are exploited for sexual purposes the child, knew nothing about it before leaving home, the child may ask her captor or madam several questions in the process of seeking clarity or coming to terms with reality. Promise asked a question that troubled her young mind:

I asked my madam - Can't you see that I am very small? If I am your daughter will you allow her to do this work? And she said nobody will bring her daughter to Burkina to do this type of work. I said okay. Then they now changed me, they made me stand on the road-- Eh, another one again making two [This is her second job posting] and I will now carry customer and when I bring the man, I will now tight [close] my legs together like this and they will now be fucking ordinary bed [she gives a sad laugh]. So, they now changed me again and put me in Ali Baba where I worked to collect 100,000CFA. That was how I came back to Nigeria, because we were sleeping after work when police came, five police... they saw many condoms, three packets of condom. That is why they took us away.

Promise's madam admitted that she would never bring her daughter to work as a prostitute but since Promise has become her property, she has to ensure compliance using every method imaginable. One of them was switching the child to several service points, from the bar to standing by the roadside. When the child found she had to comply to earn money to leave Burkina Faso, she worked for one month earning 100,000CFA (170.65 USD). Shortly after, there was a police raid and she was removed to the Nigerian embassy in Burkina Faso.

Within these shared narratives, Promise often wondered if she is still a child or a different type of child from other children (her madam's child for instance). Promise also shares lived experiences that put her several years ahead of her peers.

The money is with her. But I don't know because... in our house, if you work 5,000, or you work 10,000, you will write it. In a day, I always carry ten men. In one day. Yes, me [again, she gives me that sad smile]. True to God [swearing to indicate telling the truth], sometimes I carry fifteen. On Saturday, because they (male customers) don't go to work on Sunday, there are many men here. I will be in pain. I will be in pain. She (her madam) cared for me. She took me as her own sister. She will buy drugs for me, she will give me food, she will buy everything I will drink. Then I will sleep. They pay me CFA for each person that I carry, that is 1000CFA in Nigeria its 300 Naira (300 Naira using the exchange rate during Promise's captivity - about 1.71USD), then sometimes 2000 (about 3.34USD).

Regardless of the context within which childhood is viewed, African or Western, no child below 18 years should be forced to sleep with multiple men daily. Hoot, Tadesse and Abdella's (2006) study with child prostitutes in Ethiopia report that children were not mature enough to understand the risk involved in engaging in the profession and the precautions that should be taken. In this narrative, Promise complains about the pain she experiences after sleeping with more men than usual on hectic Saturday and Sunday nights. But it is interesting that she still commends her madam for providing care. Could she be commending her madam because in that helpless state in an unknown country and not knowing an escape route, kindness, in any form, even when it is motivated by profit, is appreciated?

\section{Advocacy to safeguard other children}

Promise vowed that after leaving the NAPTIP shelter she will begin an advocacy against the recruitment of children for trafficking. She planned to use her experience in the sex trade as a point of reference to educate other at-risk children and families:

I will tell them what I have passed through and that they should not leave their children like that. If someone comes to tell you that they want to take your daughter or son abroad, you should not allow them to do so. 
Her advocacy also builds around blaming her mother for the two months she had to withstand the sex trade:

I blame my parent and the man that took me abroad. In the first place, I did not know the man and my mother did not know the man before. I wanted to come back to Nigeria but my mother did not want me to come back. She said if I come back to Nigeria I should not reach her house.

The anti-trafficking agency tries to offer children other options apart from returning home after removal from trafficking. Promise insisted that she did not want to return home to her mother. The young girl said she is still unable to forgive her mother for making her vulnerable to the sex trade and cannot face living in the same house as her mother. When the researcher asked Promise the reintegration service she expects of the antitrafficking agency (NAPTIP) the child replied:

I will not like to go back there again. I want to go back to my sister's house.

I asked them to take me to my sister. She has two children and a hairdressing salon, she has her own shop. Yes, she will help me. I have gone there before.

The day some child survivors of trafficking were transported from Lagos to Benin, as a child from the South-South geopolitical zone, Promise should have been on that bus. She was not. The agency must have understood (and respected) her decision and based on discussions with her sister and mother, Promise remained in Lagos.

This paper focused on 17-year-old Promise, who was traumatized by the role her mother played in her trafficking to Burkina-Faso for prostitution. As far as Promise is concerned, home is a place where she does not plan to return. In the first place, home is the site of her mother's betrayal or agreement with strangers to send her off for exploitative work. Some studies show that several parents are deceived into giving out their children for prostitution. Tade (2014) confirms with his interviews with ten domestic servants in two trafficking-endemic communities in Ibadan, Nigeria, that sometimes parents are deceived by relatives to give out their children, who are subsequently recruited and dropped off in brothels in other parts of the country. His study adds that children are abused by their traffickers or others even before getting the children to their trafficking locations. However, Promise contends that even if her mother was deceived by her friend or church member into giving her child up for prostitution, she (mother) was provided an opportunity, unavailable to many, to remedy the situation. The girl recalls the absence of consoling counsel from her mother when she called from Burkina-Faso to inform her that she was asked to engage in prostitution rather than domestic work in Senegal, as she had been led to believe by her mother.

Often based on parents' analysis of family circumstances, they may decide that one of their children should seek work away from home to enhance household wellbeing. When this happens, parents decide the child that should be trafficked and who (intermediary) should be consulted to assist with the process. It is also evident that even when a child resists leaving home, as in the case of Promise, who did not want to travel to Senegal, a parent could be forceful in ensuring compliance. From the child's narrative, her mother did not try to understand why her child hesitated about traveling to work with an 'oyinbo' in Senegal. Rather than explain issues to Promise, her mother provided her with two options: traveling to Senegal or leaving her house.

Promise had to endure trafficking because she was abandoned by the one person she trusted, the same person who told her to consent to prostitution to support her family members struggling to survive in Nigeria. Understanding who benefits from children's departure from home helps determine crucial motivators for children's resilience, level of endurance during trafficking and desire to run away or remain in trafficking. Understanding who benefits from a particular child's trafficking will assist NAPTIP (other anti-trafficking agencies included), policy-makers and service providers with ascertaining appropriate shelter and reintegration services for survivors.

\section{Regional and policy implications of child trafficking for sexual exploitation}

In discussing the outcome of Promise's journey into trafficking, we contend with the fact that research in West Africa gives precedence to people trafficked outside the border and exploited for work while disregarding the situation of those within West African countries (Adepoju, 2005; Lawrence, 2010). Besides, when research is 
conducted on trafficking it is mostly focused on the trafficking of, Nigerian women for international sexual exploitation (Nwogu 2007). Osezua (2013) adds that a higher number of deportees from European countries are Nigerian women trafficked for sexual purposes, meaning that while attention is paid to the negative impact of Nigeria's image abroad, minimal attention is paid to trafficking for sexual purposes that happens within the region itself. Where female children are also sexually exploited, little data are available on their experiences because of their age and the trauma associated with discussing their experiences. This is probably because most anti-trafficking strategies underplay the internal trafficking of children with the perception that external trafficking poses the most threat to children's health and wellbeing. Currently, there are only a few empirical studies on child trafficking especially in the West African region and Sub-Saharan Africa (Adepoju, 2005; Mbakogu 2015). The methodologies for existing studies on child trafficking are not always suited to the purpose of the study and conclusions are made based on limited data (Kelly 2002; Laczka and Gramegna, 2005) which often lead to the formulation of ineffective policies for addressing the problem (Dottridge, 2003; Gozdziak and Bump, 2008; Kelly, 2002; Tyldum and Brunovskis, 2005) that children face after trafficking and reintegration with their families or communities. As Tyldum and Brunovskis (2005) point out, this issue arises because research on trafficking is still at its early stages and attention should be focused on understanding the social field regarded as trafficking and the variations "...in form of exploitation, recruitment and rehabilitation" (p. 31). More research is needed to reinforce that shift away from a one size fit all approach to reintegration or rehabilitation that is focused on returning survivors to their initial homes or family members even when that is not desired by survivors.

To buttress the impact of sex trafficking in the region, Osezua's (2013) research with 40 households selected from each of seven local government areas constituting Edo South Senatorial district which is endemic to sexual trafficking reports that sex trafficking has broken down several homes that constitute the Bini [Benin city is the capital of Edo state with Bini as one of the major tribes while the people refer to themselves as Bini people] family structure. This finding aligns with Bamgbose's (2002) suggestion that research and policy-making should be inclusive of other drivers of the trafficking of children for sexual purposes that are likely to move beyond poverty. She adds that it is not only families experiencing poverty that push their children into child prostitution. Children's movement into prostitution by their families could be reinforced by changing: “...social values, consumer lifestyles and maintaining status" (p. 574).

The diverse drivers of child trafficking for prostitution notwithstanding, with inadequate social protection packages provided by the Nigerian government to cushion the economic shortfalls experienced by families, children will continually be forced to engage in exploitative work to augment household income (Tade, 2014). Moreover, with the rise in recruitment networks, there should be more focus on educating children on the risk of recruitment for prostitution and the health implications of engaging in this activity (Hoot et al., 2006; Hounmenou, 2016). Children also return from sex trafficking without adequate mental and emotional counseling for dealing with the deeprooted impact of their experiences and how they might adjust with their families and communities. It is essential that in consultation with relevant professionals, an attempt is made to assess the health consequences of exploitative trafficking on children as well as mapping out suitable recovery time for children in need (Hossain, Zimmerman, Abas, Light and Watts, 2010).

Children that were removed from trafficking and housed in a shelter for a limited period, may have an initial springboard to weigh how the nature of their trafficking is perceived by other children before moving to the wider society. Even that is inadequate recovery since most of the children's time is consumed with investigations on the case presenting them at the anti-trafficking agency. Promise, for instance, took a long time to adjust to other children at the shelter because the first time she shared her story with a child at the shelter, she felt judged and almost treated like an outcast. The child shared that it was only when the researcher arrived at the shelter, waking her interest with the diverse art-based methods explored during the research, especially her participation in and production of a drama, that a bit of laughter and 
excitement was restored to her face and life.

\section{CONCLUSION}

Finally, those engaged in research on the removal and reintegration of trafficked children in West Africa, should not ignore the aftermath of exploitative trafficking on children. Children could be suicidal or suffer a loss of confidence (Hoot et al., 2006) especially when they do not have family members that are likely to understand and cushion the effects of their journey outside the temporary shelter. It is imperative to hear the voices of children involved in or removed from diverse forms of trafficking in West Africa, as a foundation for designing effective interventions that align with their experiences and needs. No two trafficked children or survivors of trafficking are the same; as such their experiences and needs should not be normalized under one box of interventions that fit all returning trafficked children from West Africa.

\section{Acknowledgment}

The author recognizes the contribution of child survivors of trafficking that participated in the study, and collaboration with Nigeria's National Agency for the Prohibition of Traffic in Persons and other Related Matters (NAPTIP).

\section{Funding}

The study was funded by the International Development Research Centre (IDRC), Canada

\section{REFERENCES}

Abdulraheem, S., and Oladipo, A. (2010). Trafficking in women and children: A hidden health and social problem in Nigeria. International Journal of Sociology and Anthropology, 2, 3, 34 - 39.

Adepoju, A. (2005). Review of Research and Data on Human Trafficking in Sub-Saharan Africa. International Migration, 43, 1/2, 75 98

Aghatise, E. (2004). Trafficking for Prostitution in Italy: Possible Effects of Government Proposals for Legalization of Brothels. Violence against Women, 10, 10, $1126-1155$

Agbu, O. (2003). Corruption and human trafficking: the Nigerian case. West Africa Review, 4, 1, 1 $-13$

Akor, L. (2011). Trafficking of women in Nigeria: Causes, consequences and the way forward. Corvinus Journal of Sociology and Social Policy, 2, 2, 89-110.

Bamgbose, O. (2002). Teenage prostitution and the future of the female adolescent in Nigeria. International Journal of offender therapy and comparative criminology, 46, 5, $569-585$.

BBC News (2001). 'Slave ship' timeline. Tuesday, April 17, 2001. Available from http://news.bbc.co.uk/2/hi/africa/1281391.st $\mathrm{m}$

BBC News (2001). Mystery surrounds child 'slave' ship. Tuesday, April 17, 2001. Available from

http://news.bbc.co.uk/2/hi/africa/1280991.st $\mathrm{m}$

Dottridge, M. (2002). Trafficking in children in West and Central Africa. Gender and Development, 10, 1, 38- 42

Ebigbo, P. (2003). Child abuse in Africa: Nigeria as focus. International Journal of Early Childhood, 1, 2, 95 - 113

Fayomi, O. (2009). Women, Poverty and Trafficking: A Contextual Exposition of the Nigerian Situation. Journal of Management and Social Sciences, 5, 1, 65-79

FitzGibbon, K. (2003). Modern-Day Slavery? The scope of trafficking in Africa. African Security Review, 12, 1, 81 - 89

Germano, G. (2001). "Human trafficking as a transnational problem, the responses of destination countries", Proceedings of the First Pan-African Conference on Human Trafficking, Abuja, Nigeria, 19 - 23 February 2001, 117-127.

GoŹdziak, E. (2008). On Challenges, Dilemmas, and Opportunities in Studying Trafficked Children. Anthropological Quarterly, 81, 4, $903-923$

Gozdziak, E., and Bump, M. (2008). Data and Research on Human Trafficking: Bibliography of Research-Based Literature, Final Report, Institute for the Study of International Migration, Georgetown University, Washington, DC., Available from https://www.ncjrs.gov/pdffiles1/nij/grants/22 4392.pdf

Hossain, M., Zimmerman, C., Abas, M., Light, M., and Watts, C. (2010). The relationship of 
trauma to mental disorders among trafficked and sexually exploited girls and women. American journal of public health , 100, 12, 2442 - 2449.

Hoot, J., Tadesse, S., and Abdella, R. (2006). Voices seldom heard: Child prostitutes in Ethiopia. Journal of children and poverty, 12, 2, 129 - 139.

Hounmenou, C. (2016). Exploring child prostitution in a major city in the West African region. Child Abuse \& Neglect, 59, 26 - 35.

ILO (2014). Profits and poverty: The economics of forced labour. Special Action Programme to Combat Forced Labour (SAP-FL). Fundamental Principles and Rights at Work Branch. International Labour Office, Geneva. Available from http://www.ilo.org/wcmsp5/groups/public/--ed_norm/---

declaration/documents/publication/wcms_24 3027.pdf

IOM (1996). Trafficking in women to Italy for sexual exploitation. International Organization for Migration, Migration Information Programme

James, A., and Prout, A. (1997). Constructing and Reconstructing Childhood. Basingstoke: Falmer

Kelly, L. (2002). Journeys of Jeopardy: A review of research on trafficking in women and children in Europe. International Organization for Migration (IOM).

Kielland, A., and Bjørkhaug, I. (2009). Child Mobility in West Africa: strategy, poverty or crime? On the conflict between academia and a politically 'framed' development agenda. Forum for Development Studies, 36, 2, 229 256.

Kooijmans, J., and van de Glind, H. (2010). Child slavery today. In G. Craig (Ed.), Child Slavery Now: A Contemporary Reader (pp. 21 - 41). Bristol: The Policy Press,

Laczko, F. (2002). Human trafficking: the need for better data. Migration Information Source, 1, 61-80.

Laczko, F, and Gramegna, M. (2003). Developing better indicators of human trafficking. The Brown Journal of World Affairs, X, 1, 179 194.

Lee, M. (2007). Human Trafficking. Portland:
Willan Publishing.

Nwogu, V. (2007). Nigeria. In Collateral Damage: The Impact of Anti-Trafficking Measures on Human Rights around the World. Bangkok: GAATW International Secretariat, 142 170.

Nwogu, V. (2006). Nigeria: Human Trafficking and Migration. Forced Migration Review 25, 32 34.

Marinova, N., and James, P. (2012). The Tragedy of Human Trafficking: Competing Theories and European Evidence. Foreign Policy Analysis, $1-23$.

Mbakogu, I. (2012). Child trafficking in Africa: The need for child-centred approaches. In ISIDCIDA - Strengthening Contributions to Evidence-Based Policy Making. Available from

http://www.mcgill.ca/isid/sites/mcgill.ca.isid/ files/mbakogu.pb11.pdf

Mbakogu, I. (2015). Understanding child trafficking form the point of view of trafficked children: The case of 'rescued' children in Nigeria. (Unpublished doctoral dissertation). McGill University, Montreal, Canada.

Ogwezzy, M. (2011). An appraisal of the SocioLegal issues Involved in Trafficking of Women and Children. ACTA JURIDICA HUNGARICA, 53, 2, 146 - 164

Ojomo, A. (2000), "Child Trafficking in Nigeria: Policy Perspectives". A paper presented at the FMWA \& YD. In UNICEF Conference on Child Trafficking, Benin, Nigeria.

Onimode, B. (1992). A future for Africa: Beyond the Politics of Adjustment. London: Earthscan Publications.

Onyejekwe, C. (2005). Influences of Global Human Trafficking Issues on Nigeria: A Gender Perspective. Journal of International Women's Studies, 7, 2, 141 - 151

Osezua, C. A. (2013). Changing status of women and the phenomenon trafficking of women for transactional sex in Nigeria: A qualitative analysis. Journal of International Women's Studies, 14, 3, 14 - 30.

Pile, S. (2006). The strange case of Western cities: Occult globalisations and the making of urban modernity. Urban studies, 43, 2, 305 318.

Spyrou, S. (2011). The limits of children's voices: 
From authenticity to critical, reflexive representation. Childhood, 18, 2, $151-165$

Tade, O. (2014). Recruitment and abuse of trafficked children in south-west Nigeria. African Security Review, 23, 3, 264 282.

Tyldum, G., and Brunovskis, A. (2005). Describing the Unobserved: Methodological Challenges in Empirical Studies on Human Trafficking. International Migration, 43, 1/2, 17 - 34

UNODC (2000). United Nations Convention Against Transnational Organized Crime and The Protocols Thereto. Vienna: United Nations Office on Drugs and Crime. Available

fromhttp://www.unodc.org/documents/treatie s/UNTOC/Publications/TOC\%20Convention /TOCebook-e.pdf

UNICEF (2007). Child trafficking Information Sheet: Nigeria with estimates from FOS/ILO National Child Labour Survey, 2003, Available from http://www.unicef.org/wcaro/WCARO_Nige ria_Factsheets_ChildTrafficking.pdf

Veeran, V. (2004). Working with Street Children: A Child-centred Approach. Child Care in Practice, 10, 4, 359 - 366.

Wennerholm, C. (2002). Crossing borders and building bridges: the Baltic Region Networking Project. Gender \& Development, 10, 1, 10 - 19. 